\title{
PENGARUH SELF HELP GROUP (SHG) TERHADAP PENGETAHUAN DAN SIKAP IBU DALAM MEMPERKENALKAN PENDIDIKAN SEKS BEBAS PADA REMAJA
}

\author{
Anneesha Sasqia E. Putri ${ }^{1 *}$, Kurniawan Erman Wicaksono ${ }^{2}$, Ari Damayanti Wahyuningrum ${ }^{3}$
}

${ }^{1,2}$ STIKES Widyagama Husada Malang

*Corresponding author:

Annesha Sasqia E. Putri

STIKES Widyagama Husada

Email:sasqiaanneesha@gmail.com

\begin{abstract}
One of the problems with juvenile delinquency is casual sex. The survey found that the reasons for premarital sexual relations were mostly because of curiosity (57.5\% men), just happened (38\% women) and forced by a partner (12.6\% women). Factors that influence this are the closeness of parents (mothers) and adolescents, lack of parental attention to adolescents and lack of knowledge of adolescents about the dangers of free sex. This juvenile delinquency can be resolved by sharing experiences and information about free sex education known as the Self Help Group. This study was to determine the effect of the Self Help Group (SHG) group of PKK mothers on the knowledge and attitudes of mothers in introducing free sex education to adolescents aged 10 to 19 years in Merjosari village $R W 02$ Malang. This study used quasi experiment research method. The sample were 20 respondents who had children aged 10 to 19 years who were divided into two groups, namely the intervention group and the control group. The analysis test in this study used the Wilcoxon test.Based on the Wilcoxon test on knowledge, $p=0.566(p<0.05)$ and attitude $p=0.055$ ( $p<0.05)$, which means that there is no influence of the PKK mother group's self-help group on mothers' knowledge and attitudes in introducing sex education free in adolescents aged 10 to 19 years. There is no effect of self help group on the knowledge and attitudes of mothers in introducing free sex education to adolescents aged 10 to 19 years. It is suggested to optimize the role of parents, especially mothers in increasing knowledge and attitudes of mothers in introducing free sex education to adolescents aged 10 to 19 years.
\end{abstract}

Keywords: Knowledge; Attitude; Self Help Group; Free Sex Education.

\begin{abstract}
Abstrak
Masalah kenakalan remaja salah satunya adalah perilaku seks bebas. Survei didapatkan alasan hubungan seksual pranikah sebagian besar karena penasaran atau ingin tahu (57,5\% pria), terjadi begitu saja (38\% perempuan) dan dipaksa oleh pasangan $(12,6 \%$ perempuan). Faktor yang mempengaruhi hal tersebut adalah kedekatan orang tua (ibu) dan remaja, kurangnya perhatian orang tua terhadap remaja dan kurangnya pengetahuan remaja tentang bahaya seks bebas. Kenakalan remaja ini dapat diselesaikan dengan berbagi pengalaman dan informasi mengenai pendidikan seks bebas disebut sebagai Self Help Group. Penelitian ini untuk mengetahui pengaruh Self Help Group (SHG) kelompok ibu PKK terhadap pengetahuan dan sikap ibu dalam mengenalkan pendidikan seks bebas pada remaja usia 10 sampai 19 tahun di kelurahan Merjosari RW 02 kota Malang. Metode penelitian menggunakan eksperimen semu. Sampel dalam penelitian ini menggunakan 20 responden yang mempunyai anak remaja usia 10 sampai 19 tahun yang terbagi menjadi dua kelompok, yaitu kelompok intervensi dan kelompok kontrol. Uji analisis dalam penelitian ini menggunakan uji Wilcoxon. Berdasarkan uji Wilcoxon pada pengetahuan didapatkan $\mathrm{p}=0,566$ $(\mathrm{p}<0,05)$ dan sikap $\mathrm{p}=0,055(\mathrm{p}<0,05)$ yang artinya tidak terdapat pengaruh self help group kelompok ibu PKK terhadap pengetahuan dan sikap ibu dalam mengenalkan pendidikan seks bebas pada remaja usia 10 sampai 19 tahun. Tidak terdapat pengaruh self help group kelompok ibu PKK terhadap pengetahuan dan sikap ibu dalam mengenalkan pendidikan seks bebas pada remaja usia 10 sampai 19 tahun. Disarankan untuk mengoptimalkan peran orang tua terutama ibu dalam meningkatkan pengetahuan dan sikap ibu dalam mengenalkan pendidikan seks bebas pada remaja usia 10 sampai 19 tahun.
\end{abstract}

Kata Kunci: Pengetahuan; Sikap; Self Help Group; Pendidikan Seks Bebas. 


\section{PENDAHULUAN}

Remaja adalah rentang usia 10 sampai 19 tahun, menurut Peraturan Menteri Kesehatan RI Nomor 25 tahun 2014. Jumlah kelompok usia 10 sampai 19 tahun di Indonesia menurut Sensus Penduduk 2010 sebanyak 43,5 juta atau sekitar $18 \%$ dari jumlah penduduk yang ada (Kementerian Kesehatan RI, 2017). Remaja berada pada periode emosi yang belum stabil dan penuh gejolak keingintahuan yang ingin disalurkan (Maskur, 2014). Sifat tersebut disesuaikan dengan keadaan lingkungan disekitarnya, jika lingkungan tidak mampu memfasilitasi sifat tersebut, akan mendatangkan konflik baru dalam diri remaja sehingga remaja tidak segan untuk melakukan perbuatan penyimpangan sebagai bentuk kenakalan remaja (Unayah \& Sabarisman, 2015). Bentuk perilaku kenakalan remaja, seperti melakukan penyerangan baik yang berbahaya maupun tidak, pencurian, penjualan obat terlarang, membuat panggilan teror lewat telepon, melakukan hubungan seksual, dan penyalahgunaan obatobat terlarang (Zuhairah \& Tatar, 2017).

Kenakalan remaja merupakan salah satu bentuk perilaku menyimpang. Berdasarkan Juvenile Court Statistic of Unites States, tahun 2013 terjadi 1.058.500 bermacam-macam kasus kenakalan remaja di seluruh dunia salah satunya pemerkosaan 7.500 kasus, kejahatan seks kekekrasan 9.700 kasus dan kerjahatan seks tanpa kekerasan 10.600 kasus. Juvenile Court memproses 33,8\% kasus pada setiap 1.000 remaja yang melakukan perilaku menyimpang. Remaja wanita sebanyak 293.700 kasus yang terjadi dan remaja laki-laki sebanyak 764.800 kasus (Listenbee, Furdella, \& Puzzanchera, 2015). Kenakalan remaja di Indonesia telah mengalami peningkatan. Remaja laki-laki lebih banyak pernah melakukan seks pranikah dibandingkan perempuan. Survei didapatkan alasan hubungan seksual pranikah sebagian besar karena penasaran atau ingin tahu (57,5\% pria), terjadi begitu saja (38\% perempuan) dan dipaksa oleh pasangan $(12,6 \%$ perempuan). Hal tersebut mencerminkan kurangnya pemahaman remaja tentang hidup sehat, risiko hubungan seksual dan kemampuan untuk menolak hubungan yang tidak mereka inginkan (Rambi et al., 2015).

Hasil survei dari 33 provinsi di Indonesia tahun 2015 menunjukkan 63\% dari siswa SMP dan SMA telah berpengalaman seks. Angka ini meningkat dibandingkan dengan tahun sebelumnya, dalam sebuah penelitian yang dilakukan pada tahun 2005-2006 di kota-kota besar termasuk wilayah Jakarta, Medan, Bandung, Surabaya, dan Makassar, menemukan bahwa 47\% sampai 54\% dari remaja mengaku memiliki melakukan hubungan seks sebelum menikah berrisiko masalah kesehatan seperti HIV / AIDS. Tahun 2010 didapatkan data remaja perempuan lajang yang kegadisannya hilang di Surabaya mencapai 54\%, Yogyakarta 37\%, Bandung 52\%, dan Medan 52\%. Tahun 2015 dari hasi penelitian Triningsih et al. yang dilakukan di SMA dekat lokalisasi di wilayah Kabupaten Malang dari 404 siswa yang melakukan sesks pranikah ada 116 siswa (29\%) dan sebanyak (21\%) pernah melakukan hubungan terlarang tetapi tidak mempunyai hubungan apapun. Hasil survei BKKBN tahun 2011 menunjukan $71 \%$ remaja di Indonesia mengaku pernah berpacaran. Perilaku seksual yang pernah dilakukan selama berpacaran antara lain berpegangan tangan (88\%), ciuman bibir (32\%), merangsang atau meraba (11\%), melakukan hubungan seksual pada remaja putri (2\%), melakukan hubungan seksual pada remaja putra (5\%), dan 10\% hubungan seksual tersebut dilakukan dengan teman dan pekerja seks komersial. Adanya perilaku pacaran tidak sehat dapat menimbulkan remaja mengarah pada perilaku seks bebas (Istiqomah \& Notobroto, 2017). Perilaku remaja, khususnya pengetahuan dan sikap terhadap seks dapat diperbaiki melalui konseling atau pendidikan. Pekerja kesehatan terutama perawat yang bekerja di pusat kesehatan masyarakat harus mampu mengoptimalkan peran meraka dalam menyediakan pendidikan kesehatan atau konseling tentang perkembangan seksual remaja dengan melibatkan peran keluarga dan sekolah (Nasution, 2019). 
Perilaku seks bebas memberikan dampak buruk bagi remaja pada aspek fisiologis dan psikologis remaja, beberapa dampak seks bebas antara lain kehamilan diluar nikah, aborsi, kelainan seksual, hingga penyakit kelamin. Seluruh dampak seks bebas menyebabkan remaja mengalami gangguan psikologi berupa depresi dan trauma akibat dikucilkan oleh teman, keluarga, dan masyarakat, untuk itu seks bebas harus dicegah sedini mungkin (Rahmawati \& Realita, 2017).

Faktor yang mempengaruhi perilaku seks bebas pada remaja yang paling tinggi adalah hubungan antara orang tua dengan remaja, orang tua kurang memperhatikan pergaulan anak, rendahnya taraf pendidikan keluarga, tekanan teman sebaya, pemahaman tingkat agama (religiusitas), kurangnya pengetahuan tentang bahaya seks bebas dan eksposur media pornografi (Qomarasari, 2015). Teman sebaya menjadi faktor sangat dominan dalam mempengaruhi perilaku seksual dengan remaja. Walaupun demikian keluarga terutama orang tua sangat berpengaruh dalam hubungan remaja dengan teman sebaya. Peran komunikasi orang tua dalam menginformasikan pengetahuan seks bagi remaja awal sangat penting akan tetapi banyak masalah yang terjadi dikarenakan orang tua cenderung menutupi masalah yang berhubungan dengan seks, orang tua kurang peka terhadap perkembangan fisik dan psikis remaja awal, orang tua kurang memberi ruang dialog untuk remaja awal tentang masalah seksual dan kurangnya keterbukaan orang tua terhadap anak mengenai masalah seks (Rahmawati, 2016).

Orang tua terutama ibu merupakan lingkungan sosial pertama yang dapat memberikan pengetahuan, pendidikan, dan memberi pengarahan kepada remaja jika remaja melakukan hal yang menyimpang. Kedekatan orang tua dan remaja sangat diperlukan agar remaja merasa selalu di perhatikan terutama pada remaja. Menjaga komunikasi antara orang tua dan remaja akan membantu untuk memberikan segala informasi terutama seksualitas. Dari beberapa tanggapan orang memang sangat tabu membicarakan mengenai seksualitas, apalagi mengenalkan bahaya seks bebas lebih dini pada remaja. Komunikasi orang tua dapat mencegah perilaku seksual remaja lebih tinggi. Komunikasi antara orang tua dan remaja biasanya berhubungan dengan masalah yang dihadapi oleh remaja menjadi tanggung jawab orang tua (Irawati, 2018).

Lutfiawati dan Ananingsih (2014) mengemukakan pada penelitiannya bahwa didapatkan peran orang tua yang otoriter mempunyai dampak sikap negatif bagi remaja. Orang tua yang otoriter adalah orang tua yang mempunyai rasa berkuasa dalam bemberikan pendidikan pada anaknya dan semua keaktifan, kekuasaan ada pada orang tua, semua keaktifan anak ditentukan olehnya. Orang tua mempunyai peranan sangat penting dalam mengantarkan anak pada kondisi dewasa. Ayah dan ibu menjadi sumber utama dalam memberikan informasi mengenai pengetahuan tentang pubertas kepada remaja secara benar dan terpercaya. Masa remaja merupakan masa perkembangan dinamis dalam kehidupan seorang individu. Masa ini merupakan periode transisi dari masa anak ke masa dewasa ditandai dengan kecepatan pertumbuhan dan perkembangan fisik, emosional, sosial serta mental. Peran orang tua yang otoriter membuat sikap remaja menjadi pembangkangan seperti berbohong pada orang tua, tidak diijinkan berpacaran tapi mereka diam-diam berpacaran, dan mereka saat berpacaran melakukan perilaku menyimpang seperti berciuman hal ini menyebabkan pola perilaku berpacaran bebas karena orang tua tidak bisa mengontrol (Lutfinawati \& Ananingsih, 2014).

Penelitian dari Hasan, Boham dan Rembang (2016) mengatakan peran orang tua sangat dibutuhkan anak remaja dalam memberikan informasi pengetahuan seks tepat. Orang tua merupakan pihak yang paling bertanggung jawab akan hal yang berhubungan dengan anak remaja. Mengingat anak remaja memiliki rasa ingin tahu tinggi maka masa inilah sesungguhnya penting bagi orang tua untuk diperhatikan dalam memasuki nilai dan 
norma yang berlaku dalam lingkungan keluarga masyarakat, dalam memberikan informasi pengetahuan seks pada anak usia remaja keakraban orang tua dan anak sangat penting. Dengan memposisikan orang tua sebagai sahabat anak dalam berdiskusi, anak remaja akan merasa nyaman dan lebih terbuka. Kondisi yang menyenangkan, aman, nyaman, dan bebas dari ras takut akan mempengaruhi sistim limbic pada otak anak akan berpengaruh pada serebrum yang mengandung neokorteks untuk berfikir anak (Putra, 2012). Disinilah peran orang tua menjadi sangat penting untuk memberikan informasi pengetahuan seks pada anak usia remaja yang akan menjadi bekal di masa depan. Semakin baik peran orang tua maka akan semakin baik pula sikap terhadap seks pranikah atau seks bebas pada remaja. Peran orang tua dalam memberikan pendidikan seks ini merupakan bentuk pencegahan orang tua agar anak remajanya tidak terjerumus dalam pergaulan seks bebas (Apriyani, 2016). Dalam peneliti ini melihat bahwa orang tua yang tidak memahami dengan benar pentingnya peran orang tua dalam menginformasikan pengetahuan seks pada anak yang berusia remaja, membuat anak akan mudah terjerumus dalam pergaulan bebas berujung pada perilaku seks pranikah yang nanti akan merusak masa depan mereka. Orang tua diharapkan mampu mebangun komunikasi dengan anak apalagi yang masih berusia remaja (Hasan, Boham, \& Rembang, 2016).

Rahmawati dkk (2018) menyatakan pada
penelitiannya orang tua berkewajiban dalam
perkembangan sosial anak melalui aturan, sikap dan tindakan yang dicontoh anak dari orang tua. Pendidikan pertama didapatkan dari keluarga sehingga komunikasi orang tua dengan anak sangat diperlukan. Komunikasi orang tua dapat mencegah perilaku seksual remaja beresiko tinggi. Komunikasi seksualitas orang tua-anak dapat membentuk perilaku seksual yang bertanggung jawab pada anak, terutama menambah nilai-nilai moral. Komunikasi antara orang tua dan remaja biasanya berhubungan dengan masalah yang dihadapi oleh remaja dan menjadi tanggung jawab orang tua. Berkomunikasi dalam hal seksuallitas, peran orang tua sangat penting dalam memberikan wawasan yang tepat atas pertanyaan berhubungan dengan masalah seksual. Bila orang tua tidak mampu melakukan maka anak akan mencari tahu informasi dari luar rumah seperti internet, film, dan teman. Beratnya konsekuensi negatif berhubungan dengan perilaku seksual pranikah, memastikan bahwa remaja menerima pendidikan seksualitas penting untuk perkembangan yang sehat. Pendidikan seksualitas pada anak oleh orang tua diharapkan anak dapat terhindar dari perilaku seksual pranikah (Cheryl, 2013).

Mencegah dan menangani kenakalan remaja terutama seks bebas dengan cara meningkatkan pengetahuan dan sikap ibu mengenai seberapa pentingnya mengenalkan bahaya seks lebih dini pada remaja. Upaya untuk meningkatkan pengetahuan dan sikap ibu dalam mengenalkan pendidikan seks bebas adalah membentuk kelompok mandiri atau self help group. Self help group atau kelompok swabantu merupakan suatu kelompok peer (sesama) dimana setiap anggota saling berbagi masalah baik fisik maupun emosional atau issue tertentu. Self help group ini merupakan suatu bentuk terapi kelompok yang dapat dilakukan pada berbagai situasi dan kondisi, terdiri dari dua orang atau lebih yang memiliki masalah serupa untuk saling berbagi pengalaman dan cara mengatasi masalah yang di hadapi (Keliat dkk, 2008). Pendidikan seks adalah suatu cara untuk mengurangi atau mencegah penyalah gunaan seks. Khususnya untuk mencegah dampak negatif yang tidak diharapkan seperti kehamilan yang tidak direncanakan, penyakit menular seksual, depresi, dan perasaan berdosa (Sarwono, 2011).

Berdasarkan studi pendahuluan yang telah dilakukan di kelurahan Merjosari RW 02 Kota Malang dengan metode wawancara pada ibu ketua PKK, terdapat 127 remaja dan $98 \mathrm{ibu}$ yang mempunyai anak remaja usia 10 sampai 19 tahun. Ibu ketua PKK mengatakan 3 remaja pernah melakukan seks bebas dan 10 remaja beresiko melakukan seks bebas karena sudah mengenal pacaran. 
Kelurahan Merjosari adalah kawasan padat penduduk yang notabennya banyak rumah yang dikontrakkan dan menjadi kos-kosan. Beberapa orang tua yang tinggal di daerah tersebut membebaskan anaknya berpacaran dan beberapa remaja menyalah gunakan kebebasan yang diberikan orang tua. Banyaknya kontrakan dan kos-kosan yang tidak mempunyai batasan jam malam juga akan memberikan pengaruh buruk pada remaja. Berdasarkan uraian latar belakang diatas peneliti tertarik untuk meneliti pengaruh self help group (SHG) kelompok ibu PKK untuk mengenalkan pendidikan seks bebas pada remaja usia 10 sampai 19 tahun di kelurahan Merjosari kota Malang.

\section{METODE}

Peneliti ini menggunakan metode penelitian eksperimen semu (Quasi experiment) yang bertujuan untuk mengetahui pengaruh self help group kelompok ibu PKK terhadap pengetahuan dan sikap ibu dalam mengenalkan pendidikan seks bebas. Rancangan yang digunakan dalam peneliti ini adalah non equivalent control group pretest-postest control group design, pada desain ini kelompok eksperimen maupun kelompok kontrol tidak dipilih secara random.

\section{HASIL DAN PEMBAHASAN}

\section{Data Umum}

Pada data umum atau analisa univarian disajikan data yang merupakan karakteristik responden penelitian di kelurahan Merjosari kota Malang berdasarkan usia ibu, usia anak, jenis kelamin anak, pendidikan terakhir ibu dan pekerjaan ibu adalah sebagai berikut :

Tabel 1. Karakteristik Responden Berdasarkan Usia Ibu

\begin{tabular}{ccccc}
\hline \multirow{2}{*}{ Kategori } & \multicolumn{2}{c}{ Kelompok Intervensi } & \multicolumn{2}{c}{ Kelompok Kontrol } \\
\cline { 2 - 5 } & $\mathbf{N}$ & $\begin{array}{c}\text { Presentase } \\
(\mathbf{\%})\end{array}$ & $\mathbf{N}$ & $\begin{array}{c}\text { Presentase } \\
(\mathbf{\%})\end{array}$ \\
\hline $31-36$ tahun & 2 & $20 \%$ & 3 & $30 \%$ \\
$37-42$ tahun & 3 & $30 \%$ & 3 & $30 \%$ \\
$43-52$ tahun & 5 & $50 \%$ & 4 & $40 \%$ \\
\hline Total & $\mathbf{1 0}$ & $\mathbf{1 0 0} \%$ & $\mathbf{1 0}$ & $\mathbf{1 0 0 \%}$ \\
\hline
\end{tabular}

Tabel 1. diatas menunjukan karakteristik responden berdasarkan usia ibu di Kelurahan Merjosari RW 02 didapatkan usia responden dari kelompok intervensi dan kelompok control terbanyak usia 43 - 52 tahun sebesar 5 $(50 \%)$ orang untuk kelompok intervensi dan 4 (40\%) orang kelompok kontrol.

Tabel 2. Karakteristik Responden Berdasarkan Usia Anak

\begin{tabular}{ccccc}
\hline \multirow{2}{*}{ Kategori } & \multicolumn{2}{c}{ Kelompok Intervensi } & \multicolumn{2}{c}{ Kelompok Kontrol } \\
\cline { 2 - 5 } & $\mathbf{N}$ & Presentase (\%) & $\mathbf{N}$ & Presentase (\%) \\
\hline $10-13$ tahun & 2 & $20 \%$ & 6 & $60 \%$ \\
$14-16$ tahun & 4 & $40 \%$ & 3 & $30 \%$ \\
$17-19$ tahun & 4 & $40 \%$ & 1 & $10 \%$ \\
\hline Total & $\mathbf{1 0}$ & $\mathbf{1 0 0} \%$ & $\mathbf{1 0}$ & $\mathbf{1 0 0 \%}$ \\
\hline
\end{tabular}

Tabel 2. diatas menunjukan karakteristik responden berdasarkan usia anak di Kelurahan Merjosari RW 02 didapatkan usia anak terbanyak pada kelompok intervensi usia 14 - 16 tahun dan usia 17 - 19 sama besar yaitu sebesar 4 orang (40 \%) dan untuk kelompok kontrol usia $10-13$ tahun sebesar $6(60 \%)$ orang.

Tabel 3. Karakteristik Responden berdasarkan Jenis Kelamin Anak

\begin{tabular}{ccccc}
\hline \multirow{2}{*}{ Kategori } & \multicolumn{2}{c}{ Kelompok Intervensi } & \multicolumn{2}{c}{ Kelompok Kontrol } \\
\cline { 2 - 5 } & $\mathbf{N}$ & Presentase (\%) & N & Presentase (\%) \\
\hline Laki-laki & 4 & $40 \%$ & 8 & $80 \%$ \\
Perempuan & 6 & $60 \%$ & 2 & $20 \%$ \\
\hline Total & $\mathbf{1 0}$ & $\mathbf{1 0 0 \%}$ & $\mathbf{1 0}$ & $\mathbf{1 0 0 \%}$ \\
\hline
\end{tabular}

Tabel 3. diatas menunjukan karakteristik responden berdasarkan jenis kelamin anak di Kelurahan Merjosari RW 02 didapatkan usia anak terbanyak pada kelompok intervensi perempuan sebesar $6(60 \%)$ orang dan pada kelompok kontrol laki-laki sebesar 8 orang (80\%) orang.

Tabel 4. Karakteristik Responden berdasarkan jenis pendidikan terakhir ibu

\begin{tabular}{ccccc}
\hline \multirow{2}{*}{ Kategori } & \multicolumn{2}{c}{ Kelompok Intervensi } & \multicolumn{2}{c}{ Kelompok Kontrol } \\
\cline { 2 - 5 } & $\mathbf{N}$ & Presentase (\%) & N & Presentase (\%) \\
\hline SD & - & - & 1 & $10 \%$ \\
SMP & 2 & $20 \%$ & 2 & $20 \%$ \\
SMA & 7 & $70 \%$ & 3 & $30 \%$ \\
PT & 1 & $10 \%$ & 4 & $40 \%$ \\
\hline Total & $\mathbf{1 0}$ & $\mathbf{1 0 0 \%}$ & $\mathbf{1 0}$ & $\mathbf{1 0 0 \%}$ \\
\hline
\end{tabular}

Tabel 4. diatas menunjukan karakteristik responden berdasarkan pendidikan terakhir ibu di Kelurahan Merjosari RW 02 didapatkan pada kelompok intervensi 
pendidikan terbanyak SMA sebesar 7 (70\%) orang dan kelompok kontrol pendidikan PT sebanyak 4 (40\%) orang.

Tabel 5. Karakteristik Responden berdasarkan jenis pekerjaan Ibu

\begin{tabular}{ccccc}
\hline \multirow{2}{*}{ Kategori } & \multicolumn{2}{c}{ Kelompok Intervensi } & \multicolumn{2}{c}{ Kelompok Kontrol } \\
\cline { 2 - 5 } & $\mathbf{N}$ & Presentase (\%) & N & Presentase (\%) \\
\hline Bekerja & 4 & $40 \%$ & 4 & $40 \%$ \\
Tidak Bekerja & 6 & $60 \%$ & 6 & $60 \%$ \\
\hline Total & $\mathbf{1 0}$ & $\mathbf{1 0 0} \%$ & $\mathbf{1 0}$ & $\mathbf{1 0 0 \%}$ \\
\hline
\end{tabular}

Tabel 5. diatas menunjukan karakteristik responden berdasarkan pekerjaan ibu di Kelurahan Merjosari RW 02 didapatkan tidak bekerja pada kelompok intervensi dan kelompok kontrol sebesar 6 (60\%) orang.

\section{Data Khusus}

Data khusus menggambarkan variabel independent dan variabel dependent yaitu mengetahui ada atau tidaknya pengaruh self help group kelompok ibu PKK terhadap pengetahuan dan sikap ibu dalam mengenalkan pendidikan seks bebas pada remaja usai 10 sampai 19 tahun di Kelurahan Merjosari Kota Malang. Adapun hasil analisa bivariat dari variabel diatas adalah sebagai berikut:

Tabel 6. Hasil Analisa Skor Pengetahuan Pre

\begin{tabular}{ccccc}
\hline \multirow{2}{*}{ Pengetahuan } & \multicolumn{2}{c}{ Kelompok Intervensi } & \multicolumn{2}{c}{ Kelompok Kontrol } \\
\cline { 2 - 5 } & N & Presentase \% & N & Presentase \% \\
\hline Kurang & - & - & - & - \\
Cukup & - & - & - & - \\
Baik & 10 & $100 \%$ & 10 & $100 \%$ \\
\hline Total & $\mathbf{1 0}$ & $\mathbf{1 0 0} \%$ & $\mathbf{1 0}$ & $\mathbf{1 0 0} \%$ \\
\hline
\end{tabular}

Tabel 7. Hasil Analisa Skor Pengetahuan post

\begin{tabular}{ccccc}
\hline \multirow{2}{*}{ Pengetahuan } & \multicolumn{2}{c}{ Kelompok Intervensi } & \multicolumn{2}{c}{ Kelompok Kontrol } \\
\cline { 2 - 5 } & N & Presentase \% & N & Presentase \% \\
\hline Kurang & - & - & - & - \\
Cukup & - & - & - & - \\
Baik & $\mathbf{1 0}$ & $100 \%$ & 10 & $100 \%$ \\
Total & $\mathbf{1 0}$ & $\mathbf{1 0 0} \%$ & $\mathbf{1 0}$ & $\mathbf{1 0 0 \%}$ \\
\hline
\end{tabular}

Tabel 8. Hasil Analisis Uji Wilcoxon Kelompok Intervensi

\begin{tabular}{lcc}
\hline & $\begin{array}{c}\text { Median (Minimum - } \\
\text { Maksimum) }\end{array}$ & Nilai p \\
\hline Pengetahuan Sebelum SHG & $17,50(15-20)$ & 0,472 \\
Pengetahuan Sesudah SHG & $18,10(16-20)$ & \\
\hline
\end{tabular}

Tabel 8. Hasil Analisis Uji Wilcoxon Kelompok Kontrol

\begin{tabular}{ccc}
\hline & $\begin{array}{c}\text { Median (Minimum - } \\
\text { Maksimum) }\end{array}$ & Nilai p \\
\hline $\begin{array}{c}\text { Pengetahuan Sebelum } \\
\text { Penyuluhan } \\
\begin{array}{c}\text { Pengetahuan Sesudah } \\
\text { Penyuluhan }\end{array}\end{array}$ & $17,80(13-20)$ & 0,888 \\
\hline
\end{tabular}

Hasil analisa tabel 6. dan 7. pre dan post kelompok intervensi dan kelompok kontrol pengetahuan ibu dalam mengenalkan pendidikan seks bebas. Tingkat pengetahuan ibu dalam mengenalkan pendidikan seks bebas pada remaja usia 10 sampai 19 tahun dapat dilihat dari hasil uji Wilcoxon menggunakan SPSS, dan didapatkan penjelasan bahwa kelompok intervensi terdapat 4 orang dengan hasil pengetahuan setelah dilakukan SHG lebih rendah dari pada sebelum dilakukan SHG, 1 orang tetap, dan 5 orang mempunyai pengetahuan yang lebih baik dari sebelum dilakukan SHG. Mean Ranks atau rata-rata dari posttest kelompok intervensi adalah 4,12 dan Sum of Ranks 16,50 sedangkan untuk pretest Mean Ranks 5,70 dan Sum of Ranks 28,50. Pada kelompok kontrol didapatkan penjelasan bahwa 4 orang dengan hasil pengetahuan setelah, 2 orang tetap, 4 orang mempunyai pengetahuan yang lebih baik dari sebelumnya. Mean Ranks atau ratarata dari posttest kelompok kontrol adalah 4,25 dan Sum of Ranks 17,00 sedangkan untuk pretest Mean Ranks 4,75 dan Sum of Ranks 19,00.

Untuk dasar pengambilan hipotesis jika nilai Asymp Sign $<0,05$ maka hipotesis dapat diterima. Dan hasil uji nilai Asymp Sign pada pretest dan posttest mengenalkan pendidikan seks bebas pada kelompok intervensi adalah $0.472<0.05$ berarti dapat disimpulkan bahwa hipotesis ditolak dan pada kelompok kontrol adalah 0,888 $<0,05$. Artinya tidak ada perbedaan antara hasil uji kuesioner pengetahuan untuk Pretest dan Posttest pada keompok intervensi dan kelompok kontrol. Sehingga dapat disimpulkan bahwa "tidak ada pengaruh self help group kelompok ibu PKK terhadap pengetahuan ibu dalam mengenalkan pendidikan seks bebas pada remaja usia 10 sampai 19 tahun. 
Tabel 10. Hasil Analisa Skor Sikap post

\begin{tabular}{ccccc}
\hline \multirow{2}{*}{ Pengetahuan } & \multicolumn{2}{c}{$\begin{array}{c}\text { Kelompok } \\
\text { Intervensi }\end{array}$} & Kelompok Kontrol \\
\cline { 2 - 5 } & $\mathbf{N}$ & Presentase \% & N & Presentase \% \\
\hline Kurang & - & - & - & - \\
Cukup & 4 & $35 \%$ & 3 & $30 \%$ \\
Baik & 6 & $65 \%$ & 7 & $70 \%$ \\
\hline Total & $\mathbf{1 0}$ & $\mathbf{1 0 0} \%$ & $\mathbf{1 0}$ & $\mathbf{1 0 0} \%$ \\
\hline
\end{tabular}

Tabel 11. Hasil Analisis Uji Wilcoxon Kelompok Intervensi

\begin{tabular}{ccc}
\hline & $\begin{array}{c}\text { Median (Minimum - } \\
\text { Maksimum) }\end{array}$ & Nilai p \\
\hline Sikap Sebelum SHG & $\begin{array}{c}59(52-64) \\
\text { Sikap Sesudah SHG }\end{array}$ & $61,30(52-73)$ \\
\hline
\end{tabular}

Tabel 12. Hasil Analisis Uji Wilcoxon Kelompok Kontrol

\begin{tabular}{lcc}
\hline & $\begin{array}{c}\text { Median } \\
\text { (Minimum - } \\
\text { Maksimum) }\end{array}$ & Nilai p \\
\hline Sikap Sebelum Penyuluhan & $58,50(53-67)$ & 0,091 \\
Sikap Sesudah Penyuluhan & $61,30(55-69)$ & \\
\hline
\end{tabular}

A. Tingkat Pengetahuan Responden Dalam

\section{Mengenalkan Pendidikan Seks Bebas Sebelum pada Kelompok Intervensi}

Sebelum dilakukan self help group diberikan kuesioner untuk mengetahui tingkat pengetahuan responden yang mendapat kategori kurang sebanyak 0 (0\%), cukup $0(0 \%)$, dan baik sebanyak 10 orang (100\%). Penelitian yang dilakukan oleh Umah \& Saputro (2016) tingkat pengetahuan responden pretest dalam kategori kurang sebanyak 17 (57\%) orang, cukup 7 (23\%) orang, dan baik 6 (20\%) orang.

Penelitian ini menunjukkan tingkat pengetahuan orang tua dalam mengenalkan pendidikan seks bebas terdapat 2 indikator yaitu tahu dan memahami. Pada indikator tahu terdapat 10 item pre terdapat 1 item yang menunjukkan bahwa responden kurang mengetahui beberapa remaja lebih mempercayai teman sebaya dibandingkan orang tua dan teman sebaya dianggap lebih mengeti dibandingkan orang tua. Pada indikator memahami terdapat 10 item pre terdapat 1 item yang menunjukkan bahwa responden kurang memahami remaja yang diberikan kepercayaan tetapi ada yang menyalahgunakan kepercayaan tersebut dengan

\begin{tabular}{ccccc}
\hline \multirow{2}{*}{ Pengetahuan } & \multicolumn{2}{c}{ Kelompok Intervensi } & \multicolumn{2}{c}{ Kelompok Kontrol } \\
\cline { 2 - 5 } & $\mathbf{N}$ & Presentase \% & N & Presentase \% \\
\hline Kurang & - & - & & \\
Cukup & 5 & $50 \%$ & 6 & $60 \%$ \\
Baik & 5 & $50 \%$ & 4 & $40 \%$ \\
\hline Total & $\mathbf{1 0}$ & $\mathbf{1 0 0} \%$ & $\mathbf{1 0}$ & $\mathbf{1 0 0} \%$ \\
\hline
\end{tabular}

melakukan hal negatif. Sehingga, hal tersebut membuat responden tidak memberikan kepercayaan pada remaja.

\section{B. Tingkat Pengetahuan Responden Dalam \\ Mengenalkan Pendidikan Seks Bebas Sesudah pada Kelompok Intervensi}

Sesudah dilakukan self help group diberikan kuesioner untuk mengetahui tingkat pengetahuan responden yang mendapat kategori kurang sebanyak 0 $(0 \%)$, cukup $0(0 \%)$, dan baik sebanyak 10 orang $(100 \%)$. Penelitian yang dilakukan oleh Umah \& Saputro (2016) tingkat pengetahuan responden posttest dalam kategori kurang 6 (20\%) orang, cukup 9 (30\%) orang, dan baik 15 (50\%) orang.

Penelitian ini menunjukkan tingkat pengetahuan orang tua dalam mengenalkan pendidikan seks bebas terdapat 2 indikator yaitu tahu dan memahami. Pada indikator tahu terdapat 10 item post terdapat 1 item yang menunjukkan bahwa responden kurang mengetahui beberapa remaja lebih mempercayai teman sebaya dibandingkan orang tua dan teman sebaya dianggap lebih mengeti dibandingkan orang tua. Pada indikator memahami terdapat 10 item post terdapat 2 item yang menunjukkan bahwa responden kurang memahami remaja yang diberikan kepercayaan tetapi ada yang menyalahgunakan kepercayaan tersebut dengan melakukan hal negatif. Sehingga, hal tersebut membuat responden tidak memberikan kepercayaan pada remaja.

\section{Tingkat Sikap Responden Dalam Mengenalkan Pendidikan Seks Bebas Sebelum pada Kelompok Intervensi}

Sebelum dilakukan self help group diberikan kuesioner untuk mengetahui tingkat sikap responden yang mendapat kategori kurang sebanyak $0(0 \%)$, cukup 
11 (55\%), dan baik 9 (45\%). Penelitian yang dilakukan oleh Umah \& Saputro (2016) tingkat sikap responden pretest dalam kategori kurang sebanyak 19 (63\%) orang, cukup $5(17 \%)$ orang, dan baik $6(20 \%)$ orang.

Penelitian ini menunjukkan tingkat sikap responden memngenalkan pendidikan seks bebas pada remaja terdapat 4 indikator yaitu menerima, merespon, menghargai dan bertanggung jawab. Indikator menerima terdapat 5 item dan 2 item pre menunjukkan bahwa responden kurang menerima bahwa remaja masih membutuhkan bimbingan orang tua terutama ibu untuk mengenalkan bahaya seks bebas kepada remaja. Indikator merespon terdapat 5 item dan 5 item pre menunjukkan bahwa responden merespon jika pendidikan seks bebas diberikan sejak dini dan orang tua masih menganggap tabu untuk membicarakan seksualitas. Indikator menghargai terdapat 5 item dan 2 item pre menunjukkan bahwa responden kurang menghargai responden lain yang sudah memberikan pendidikan seksualitas lebih awal pada remaja karena masih dianggap tabu. Indikator bertanggung jawab terdapat 5 item dan 1 item pre menunjukkan bahwa responden bertanggung jawab pada remaja untuk memberitahukan bahaya melakukan seks bebas dan aborsi masih ragu-ragu untuk memberitahukan kepada remaja.

\section{Tingkat Sikap Responden Dalam Mengenalkan} Pendidikan Seks Bebas Sesudah pada Kelompok

\section{Intervensi}

Sesudah dilakukan self help group diberikan kuesioner untuk mengetahui tingkat sikap responden yang mendapat kategori kurang sebanyak $0(0 \%)$, cukup 7 (35\%), dan baik 13 (65\%). Penelitian yang dilakukan oleh Umah \& Saputro (2016) tingkat sikap responden posttest dalam kategori kurang 6 (20\%) orang, cukup 8 (27\%) orang, dan baik 16 (53\%) orang.

Sikap responden sesudah dilakukan self help group dalam mengenalkan pendidikan seks bebas berdasarkan tingkatan sikap yaitu pada tingkat menerima informasi dan pengalaman dari anggota lain, merespon dengan bertukar pengalaman dalam mengenalkan pendidikan seks bebas pada anak remaja dan responden merepon untuk mengisi kuesioner yang telah diberikan, untuk tingkat menghargai responden menghargai pendapat dan pengalaman orang lain yang telah diutarakan responden lain.

\section{E. Tingkat Pengetahuan Responden Dalam Mengenalkan Pendidikan Seks Bebas Sebelum pada Kelompok Kontrol}

Sebelum dilakukan pendidikan kesehatan tentang seks bebas diberikan kuesioner untuk mengetahui tingkat pengetahuan responden yang mendapat kategori kurang sebanyak $0(0 \%)$, cukup $0(0 \%)$, dan baik sebanyak 10 orang (100\%). Penelitian yang dilakukan oleh Handayani \& Wardani (2019) tingkat pengetahuan responden pretest dalam kategori kurang sebanyak 10 (56\%) orang dan baik 8 (44\%) orang.

Penelitian ini menunjukkan tingkat pengetahuan orang tua dalam mengenalkan pendidikan seks bebas terdapat 2 indikator yaitu tahu dan memahami. Pada indikator tahu terdapat 10 item post terdapat 2 item yang menunjukkan bahwa responden kurang tahu mengenai anak remaja yang sering mempercayai teman di bandingkan orang tua karena teman dianggap orang yang paling mengerti dan tidak menghakimi. Pada indikator memahami terdapat 10 item yang menunjukkan bahwa responden sudah memahami pentingnya memberikan pendidikan agama sedini mungki kepada anak agar anak terhindar dari perilaku menyimpang terutama seks bebas.

\section{F. Tingkat Pengetahuan Responden Dalam Mengenalkan Pendidikan Seks Bebas Sesudah pada Kelompok Kontrol}

Sesudah dilakukan pendidikan kesehatan tentang seks bebas diberikan kuesioner untuk mengetahui tingkat pengetahuan responden yang mendapat kategori kurang 
sebanyak $0(0 \%)$, cukup $0(0 \%)$, dan baik sebanyak 10 orang (100\%). Penelitian yang dilakukan oleh Handayani \& Wardani (2019) tingkat pengetahuan responden posttest dalam kategori kurang 9 (50\%) orang dan baik 9 (50\%) orang.

Penelitian ini menunjukkan tingkat pengetahuan orang tua dalam mengenalkan pendidikan seks bebas terdapat 2 indikator yaitu tahu dan memahami. Pada indikator tahu terdapat 10 item post terdapat 1 item yang menunjukkan bahwa responden kurang tahu mengenai anak remaja yang sering mempercayai teman di bandingkan orang tua karena teman dianggap orang yang paling mengerti dan tidak menghakimi. Pada indikator memahami terdapat 10 item post terdapat 1 item yang menunjukkan bahwa responden kurang memahami pentingnya memberikan pendidikan agama sedini mungki kepada anak agar anak terhindar dari perilaku menyimpang terutama seks bebas.

\section{G. Tingkat Sikap Responden Dalam Mengenalkan} Pendidikan Seks Bebas Sebelum pada Kelompok

\section{Kontrol}

Sebelum dilakukan pendidikan kesehatan tentang seks bebas diberikan kuesioner untuk mengetahui tingkat sikap responden yang mendapat kategori kurang sebanyak $0(0 \%)$, cukup $6(60 \%)$, dan baik sebanyak 4 orang (40\%). Penelitian yang dilakukan oleh Handayani \& Wardani (2019) tingkat pengetahuan responden pretest dalam kategori kurang sebanyak 10 (56\%) orang dan baik 8 (44\%) orang.

Penelitian ini menunjukkan tingkat sikap responden memngenalkan pendidikan seks bebas pada remaja terdapat 4 indikator yaitu menerima, merespon, menghargai dan bertanggung jawab. Indikator menerima terdapat 5 item dan 1 item pre menunjukkan bahwa responden masih ragu-ragu memberikan ijin untuk berpacaran karena jika di pebolehkan akan disalahgunakan dan jika dilarang akan menyembunyikan hal tersebut. Indikator merespon terdapat 5 item dan 1 item pre menunjukkan bahwa responden merespon jika pendidikan seks bebas diberikan sejak dini lebih baik meskipun beberapa orang masih menganggap tabu untuk membicarakan seksualitas. Indikator menghargai terdapat 5 item dan 2 item pre menunjukkan bahwa responden menghargai responden lain yang sudah memberikan pendidikan seksualitas lebih awal pada remaja. Indikator bertanggung jawab terdapat 5 item dan 3 item pre menunjukkan bahwa responden bertanggung jawab pada remaja untuk memberitahukan bahaya melakukan seks bebas dan aborsi.

\section{H. Tingkat Sikap Responden Dalam Mengenalkan Pendidikan Seks Bebas Sesudah pada Kelompok}

\section{Kontrol}

Sesudah dilakukan pendidikan kesehatan tentang seks bebas diberikan kuesioner untuk mengetahui tingkat sikap responden yang mendapat kategori kurang sebanyak 0 (0\%), cukup 3 (30\%), dan baik sebanyak 7 orang $(70 \%)$. Penelitian yang dilakukan oleh Handayani \& Wardani (2019) tingkat pengetahuan responden posttest dalam kategori kurang 10 (56\%) orang dan baik 8 (44\%) orang.

Penelitian ini menunjukkan tingkat sikap responden memngenalkan pendidikan seks bebas pada remaja terdapat 4 indikator yaitu menerima, merespon, menghargai dan bertanggung jawab. Indikator menerima terdapat 5 item dan 3 item post menunjukkan bahwa responden menerima bahwa remaja diberikan pendidikan seks bebas agar remaja terhindar dari perilaku seks pranikah. Indikator merespon terdapat 5 item dan 2 item post menunjukkan bahwa responden merespon jika pendidikan seks bebas diberikan sejak dini lebih baik meskipun beberapa orang masih menganggap tabu untuk membicarakan seksualitas. Indikator menghargai terdapat 5 item dan 4 item post menunjukkan bahwa responden menghargai responden lain yang sudah memberikan pendidikan seksualitas lebih awal pada remaja. Indikator bertanggung jawab terdapat 5 item dan 3 item post menunjukkan bahwa responden bertanggung jawab pada 
remaja untuk memberitahukan bahaya melakukan seks bebas, aborsi dan penyakit kelamin yang akan diderita jika melakukan hubungan seks bebas.

\section{Menganalisis Pengaruh Self Help Group Kelompok} Ibu PKK Terhadap Pengetahuan dan Sikap Ibu dalam Mengenalkan Pendidikan Seks Bebas pada Remaja Usia 10 sampai 19 tahun

Penelitian ini menggunakan kuesioner untuk mengukur tingkat pengetahuan dan sikap ibu dalam mengenalkan pendidikan seks bebas. Pada kuesioner pengetahuan terdapat 2 indikator yaitu tahu dan memahami. Pada kuesioner sikap terdapat 4 indikator yaitu menerima, merespon, menghargai dan bertanggung jawab. Penelitian ini menggunakan 2 kelompok yaitu kelompok intervensi dan kelompok kontrol, dimana masing-masing kelompok terdapat 10 anggota. Kelompok intersvensi memberikan kesempatan kepada anggota untuk saling tukar pengalaman dalam memberikan pendidikan seks bebas pada anak. Pada setiap anggota berkewajiban untuk mengutarakan pendapatnya tetapi pada kelompok ini hanya sebgaian saja yang merespon dan sebagian hanya menyimak apa yang didiskusikan, sebelum dan sesudah dilakukan self help group diberikan kuesioner pengetahuan dan sikap. Pada kelompok kontrol di berikan pendidikan seks bebas, sebelum dan sesudah diberikan pendidikan skes bebas diberikan kuesioner pengetahuan dan sikap. Hal tersebut bertujuan untuk mengetahui tngkat pengetahuan dan sikap ibu dalam memberikan pendidikan seks bebas pada remaja.

\section{KESIMPULAN}

Berdasarkan hasil penelitian pengaruh self help group kelompok ibu PKK terhadap pengetahuan dan sikap ibu dalam mengenalkan pendidikan seks bebas pada remaja usia 10 sampai 19 tahun di Kelurahan Merjosari RW 02 Kota Malang.
1. Tingkat pengetahuan respoden sebelum dilakukan self help group (SHG) didapatkan pengetahuan 20 responden menunjukkan dalam kategori baik.

2. Tingkat sikap responden sebelum dilakukan self help group (SHG) didapatkan sikap responden dalam kategori cukup 11 (55\%) orang dan baik 9 (45\%) orang.

3. Tingkat pengetahuan respoden sesudah dilakukan self help group (SHG) didapatkan pengetahuan 20 responden menunjukkan dalam kategori baik.

4. Tingkat sikap responden sesudah dilakukan self help group (SHG) didapatkan sikap responden dalam kategori cukup 7 (35\%) orang dan baik $13(65 \%)$ oranng.

5. Tidak terdapat pengaruh self help group kelompok ibu PKK terhadap pengetahuan dan sikap ibu dalam mengenalkan pendidikan seks bebas pada remaja usia 10 sampai 19 tahun. Hasil pengolahaan data berdasarkan uji Wilcoxon pada pengetahuan didapatkan $\mathrm{p}=0,566(\mathrm{p}<0,05)$ dan sikap $\mathrm{p}=0,055(\mathrm{p}<0,05)$.

\section{UCAPAN TERIMA KASIH}

Kami mengucapkan terima kasih kepada seluruh pihak yang turut berkontribusi dalam penelitian ini sehingga penelitian ini dapat terlaksana dengan baik.

\section{DAFTAR RUJUKAN}

Anugraheni, E., Lutvianti, N, Rokhmah, D. (2012). Hubungan Pengetahuan dan Sikap Orang Tua dalam Pemberian Pendidikan Seks pada Remaja (Studi di Kecamatan Sumbersari Kabupaten Jember), Jurnal Ilmiah Hasil Penelitian Mahasiswa 2012 vol.5 No.2 April 2012.

Apriyani. (2016). Hubungan peran Orang Tua dalam Pendidikan Seks dengan Sikap terhadap Seks Pranikah pada Remaja di SMA Muhammadiyah 2. Yogyakarta: Universitas 'Aisyiyah.

Arikunto, S. (2010). Prosedur Penelitian Suatu Pendekatan Praktek. Jakarta: Rineka Cipta.

Asiah, M, D. (2012). "Hubungan Tingkat Pendidikan 
dengan Pengetahuan Kesehatan Reproduksi Ibu

Rumah Tangga di Desa Rukoh Kecamatan Syiah

Kuala Banda Aceh”. Jurnal Penelitian FKIP Biologi vol.2 No.1 Juni 2012.

Azwar, S. (2012). Penyusunan Skala Psikologi (Edisi 2). Yogyakarta: Pustaka Pelajar.

Dewi, M., \& Wawan, M. (2011). Teori \& Pengukuran Pengetahuan, Sikap dan Perilaku Manusia. Yogyakarta: nuha Medika.

Dyson S. (2010). Parents' Attitudes To Sexual Health Education In Wa School. Melbourne: Department Of Health, Western AAustralia.

Geetha, S., \& Babu, S. (2016). Self Help Group: An Effective Approach to Women Empowerment in Indian. Asian Journal of Innovative Research, 1(2), 22-28.

Hameed, W. U., Mohammad, H., Shahar, H. K. (2018). Pursuing Goal of Self-Sustainbility but Leads towards More Instability: Challenges and Way Forward of Self-Help Groups (SHGs). International Journal of Business and Tehnopreneurship Volume 8 No 1, Feb 2018 [67-76].

Hasan, R., Boham, A., \& Rembang, M. (2016). Peran Orang Tua Dalam Menginformasikan Pengetahuan Seks Bagi Remaja Di Desa Picuan Kecamatan Motoling Timur Kabupaten Minahasa Selatan. Acta Diurna, $V(3)$.

Haryani D, Wahyuningsih, Haryani K. (2015). Peran Orang tua Berhubungan dengan Perilaku Seksual Pra Nikah Remaja di SMK 1 Sedayu. Jurnal Ners dan Kebidanan Indonesia, 3(3): 140-144.

Istiqomah, N., \& Notobroto, H. B. (2017). Pengaruh Pengetahuan, Kontrol Diri terhadap Perilaku Seksual Pranikah di Kalangan Remaja SMK di Surabaya. Jurnal Biometrika Dan Kependudukan, $5(2)$, 125.

https://doi.org/10.20473/jbk.v5i2.2016.125-134

Kementerian Kesehatan RI. (2017). Infodatin Reproduksi Remaja-Ed.Pdf. Situasi Kesehatan Reproduksi
Remaja, pp. 1-8.

Listenbee, R. L., Furdella, J., \& Puzzanchera, C. (2015). Report Series Delinquency Cases in Juvenile Court , 2013.

Lutfinawati, D., \& Ananingsih, I. (2014). Relationship Between Parents Role With Teen's Attitude About Free Sex. Jurnal Ners Dan Kebidanan (Journal of Ners and Midwifery), 1(2), 098-103. https://doi.org/10.26699/jnk.v1i2.art.p098-103

Madani, Y (2014). Pendidikan Seks usia Dini Bagi Anak Muslim.Jakarta: Zahra Publishing House.

Maskur, S. (2014). Jurnal Manajemen Pendidikan Islam. Jurnal Al-Idarah, 1(1).

Maulida I, Nisa J, Prastiwi R, Hendriana Y. (2017). Analisis Model Faktor Perilaku Menyusui Dini di Puskesmas Kesamiran Kabupaten Tegal. Prosiding Seminar Nasional Kebidanan dan call for Paper 16 Maret 2017

Meilani, N \& Shaluhiyah, Z \& Suroputro, A. (2014). Perilaku Ibu dalam Memberikan Pendidikan Seksualitas pada Remaja Awal di Kabupaten Magelang. Vol 8 No.8 Jurnal Kesehatan Masyarakat Nasional: Universitas Diponegoro.

Mugihardi, Rose, E. M., \& Afand, M. (2016). Efektifitas Self Help Group Terhadap Kualitas Hidup pada Pasien Gagal Ganjil Kronis. Prosiding Interdisciplinary Postgraduate Student Conference $1^{\text {st }},(6), 186-190$.

Nasution, S. S. (2019). Effectiveness Of Health Education In Increasing Knowledge And.

Notoatmodjo. (2012). Metodologi Penelitian Kesehatan. Jakarta: Rineka Cipta.

Novianti R, Hodikoh A, Nugroho N. (2018). Komunikasi, Informasi dan Edukasi (KIE) Meningkatkan Pengetahuan tentang Pencegahan Perilaku Seksual Pranikah pada Remaja, Jurnal Keperawatan dan Kebidanan, 8(1): 33-43

Nursalam. (2013). Konsep \& Penerapan Metodologi Peneliti Ilmu Keperawatan Pedoman Skripsi, Tesis 
dan Instrumen Penelitian Keperawatan. Jakarta: Salemba Medika.

Permatasai, Intan. (2014). Pengaruh Self Help Group (SHG) Terhadap Pengetahuan dan Sikap Merokok pada Siswa Salah Satu SMA di Yogyakarta. Universitas Muhammadiyah Yogyakarta.

Qomarasari, D. (2015). Hubungan antara Peran Keluarga, Sekolah, Teman Sebaya, Pendapatan Keluarga, Media Informasi dan Norma Agama dengan Perilaku Seksual Remaja SMA di Surakarta. (Tesis tidak dipublikasi). Universitas Sebelas Maret Surakarta, Indonesia.

Rahmawati, A., \& Realita, F. (2017). Pengetahuan dan Perilaku Seksual Pranikah Remaja. Jurnal Komunikasi Kesehatan, 8(1), 45-61.

Rahmawati, I., (2015). Peran Keluarga dalam Pengasuhan Anak. Jurnal SMP 1 Undaan Kudus, Jawa Tengah: tidak diterbitkan.

Rambi, C. A., Gansalangi, F., Tumbale, E., Keperawatan, D. P., Negeri, P., Utara, N., \& Keperawatan, S. P. (2015). Faktor-Faktor Yang Berhubungan Dengan Perilaku Seksual Pranikah Pada Remaja Di Sma X Kabupaten Sangihe. 74-84.

Ririnisahawaitun. (2010). Pengaruh Kelompok Swabantu (Self Help Group) Terhadap Tingkat Stres OrangTua Dengan Anak Retardasi Mental Di SLB Negeri 3 Yogyakarta, online, (http://publikasi.umy.ac.id/index.php/ar ticle/view File/2371/1145), diakses 27 Nopember 2014.

Roifah, Ifa. (2017). Peningkatan Kualitas Hidup Penderita Kusta Dengan Menggunakan Metode Self Help Group (SHG). STikes Bina Sehat PPNI Mojokerto.

Salmiyati, S. (2018) Pengaruh Self Help Group terhadap Pengetahuan tentang Hipertensi. Journal of Health Studies, 2(1), 75-83. http://doi.org/10.31101/jhes.428

Sarwono, S., W., (2013). Psikologi Remaja. Edisi Revisi. Jakarta: PT. Gaja Gravindo.
Septiani E, Praswitasari S, Emilia O. (2016). Evektivitas Promosi Kesehatan Menggunakan Audiovisual terhadap Perubahan Persepsi Ibu tentang Pendidikan Seks untuk Anak Prasekolah. Berita Kedokteran Masyarakat, 32(1); 421-426

Swain, R. B., \& Varghese, A. (2013). Develery Mechanisms and Impac of Microfinance Training in Indian Self-Help Group. Journal of International Development, 25(1), 11-21.

Testoni, I., Francescon. E., Leo, D. D., Santini, A., Zamperini, A. (2019). Forgiveness and Blame Among Suicide Survivors: A Qualitative Analysis on Reports of 4-Year Self-Help-Group Meetings. Community Mental Health Journal 55;360-368.

Tjandra, E., \& Karunia, N. 2012. Bunda, Seks itu apa sih? Cara Cerdas dan Bijak Menjelaskan Seks pada Anaka. Jakarta: PT Gramedia Pustaka Utama.

Unayah, N., \& Sabarisman, M. (2015). Fenomena Kenakalan Remaja dan Kriminalitas. Sosio Informa, 1(2), 121-140. Retrieved from https://media.neliti.com/media/publications/52810ID-fenomena-kenakalan-remaja-dan-kriminalit.pdf Utami, T. W, (2008). Pengaruh Self -Help Group Terhadap Kemampuan Keluarga Dalam Merawat Klien Gangguan Jiwa Di Kelurahan Sindang Bartang Bogor Tahun 2008. Hasil tesis Fakultas Keperawatan Universitas Indonesia diakes 27 Desember 2016.

Wahid, A., (2015). Konsep Orang Tua dalam Membangun Kepribadian Anak. Jurnal Sekolah Tinggi Agama Islam Ma'arif Magentan: tidak diterbitkan.

Wahyuni, D. W., (2016). Pengaruh Self Help Group Terhadap Tingkat Pengetahuan Penderita Tentang Pencegahan Penularan TB Paru. Adi Husada Nursing Journal Vol. 2, No.1.

Zakudin, A, \& Shaluhiyah, Z. (2016). Perilaku Kebersihan Diri (Personal Hygiene) Santri di Pondok Pesantren Wilayah Kabupaten Brebes akan 
Terwujud Jika Didukung dengan Ketersediaan

Sarana Prasarana. Jurnal Promosi Kesehatan Indonesia Vol. 11/No. 2/.

Zuhairah, \& Tatar, F. M. (2017). Hubungan Antara
Keterlibatan Ayah Dalam Pengasuhan Dengan Kenakalan Remaja di Kota Banda Aceh. 11(1), 4652. https://doi.org/10.13170/jp.11.1.8315 